\title{
Introduction - Plausible, Norms of Warfare: Reducing the Gap Between the Normative and the Empirical
}

\author{
Ariel Colonomos \\ CNRS-CERI, Sciences Po, Paris, France \\ Ariel.colonomos@sciencespo.fr \\ Richard Beardsworth \\ Politics and International Studies (POLIS), University of Leeds, Leeds, UK \\ r.beardsworth@leeds.ac.uk
}

\begin{abstract}
This special issue argues in favor of a new approach to the study of norms of warfare, which combines a normative analysis of ethical problems arising in war with an explanatory analysis of the use of force. Norms of warfare go as far back as Antiquity, and their study has followed a long historical path. In recent years, the ethics of war, mostly grounded in philosophy, has considerably expanded as a field. Notwithstanding such efforts to refine our normative knowledge of what should be just norms for the use of force, we argue that a more interdisciplinary approach is required to orient the study of the laws of war. In this Special Issue, proposals are made that, along with normative analysis, bring to the discussion not only disciplines such as political science and international relations, but also social theory, psychology and the neurosciences. We argue from a non-ideal perspective, that in order for norms to be just, they need to be 'plausible' for those who should abide by them. They also need to make sense in the context of democratic societies that favor a pluralistic debate on justice and ethics. Epistemically, we argue that, in order to understand if norms are plausible and just, reducing the gap between the normative and the empirical is required.
\end{abstract}

\section{Keywords}

ethics of war - political theory - international relations - just war - social sciences - psychology 
This special issue constitutes an attempt to identify an evolution in the field of the study of the norms of warfare. It is also an attempt to provide responses to theoretical questions that have become important both in the current evolution in the field of the ethics of war and in the current evolution of international politics. ${ }^{1}$

Sociologists and epistemologists have taught us that knowledge is in part the reflection of historical and social change. ${ }^{2}$ The field of the 'ethics of war' has indeed evolved over time, and it is important to rehearse this evolution. It is important because it enables us to elaborate an approach that addresses the specific problems that those who are using force are confronted with today.

The concern of this Special Issue redounds to a specific political and epistemic context. Politically, the important role of non-state actors-whose presence has important consequences on the shaping of the norms of warfare-should now be fully acknowledged. It should also be fully acknowledged that the dividing-line between the international and the domestic has become very blurred and that, in the context of global terrorism and asymmetrical warfare most notably, norms which authorise the use of force take into account this collapse of the international/domestic divide. At the theoretical level this Special Issue considers that an important moment has been reached in the historical dialectic between normative theories and the social sciences: one that concerns the substantive approach to norms and the constitutive analysis of them. Bridging this gap also presupposes taking into consideration facts and the empirical realm in general. It is the contention of this Special Issue that the substantive and the constitutive are increasingly entangled in each other and that there is a pressing need to confront the epistemic challenge implied by this entanglement.

\section{The substantive and constitutive dialectic in historical perspective}

The normative discussion on warfare can be traced back to the Antiquity and even further back in time within religion (as, for example, in Judaism). ${ }^{3}$ The just war tradition became, later, deeply anchored in Christian culture and theology.

1 The paper in this this special issue were first presented at one-day conference at Sciences Po, Paris in December 2016 and at an ISA one-day workshop in San Francisco (March 2018). We wish to express our gratitude to both Sciences Po/CERI and the ISA for funding and hosting these two meetings.

2 As in the Kuhnian tradition: see Kuhn, The Structure of Social Revolutions, (1962).

3 See, for example, James Turner Johnson, 'Thinking comparatively', (2008), pp. 157-79. 
The Middle Ages also constituted an important moment in the debate on the laws of war-to the extent that the mediaeval ethos of chivalry still inspires particular norms of conduct in warfare and the use of particular weaponry.

In this regard the case of chemical weapons is interesting. Alberico Gentili, one of the main just war tradition authors of the early seventeenth century, argued that poison ought to be banned from the conduct of war. ${ }^{4}$ Echoing the tradition of chivalry and its ethos, poison was, for him, a treacherous weapon. This approach to ethics continues: the ban on poison lives again in the norm banning chemical weapons. ${ }^{5}$ The seventeenth century is a decisive moment in the history of the laws of war, as, philosophers such as Gentili, and more importantly Grotius, introduced and developed most of the standards, such as self-defence and just cause, that constitute the just war tradition and that have inspired the writing of international law and international humanitarian law (IHL) ever since. Texts in the just war tradition are substantial: they raise normative questions that those who fight should address in order to justify resort to arms. They also include an empirical component; historical examples are always used to raise those questions. Similarly, authors in this volume use historical or contemporary examples in order to raise normative questions. That said, this Special Issue provides a more thorough use of the empirical. Historical examples are not mere illustration: contributions to this Special Issue use the social sciences - mostly sociology, political science, psychology and International Relations - as explanatory tools of human behavior.

During the Renaissance debates about the use of force mirrored the division of power between kingdoms in the post-Westphalian international order. Just war tradition treatises were intended to limit the use of force, to prevent wanton destruction, and to warn princes and kings about the negative consequences of political and military imprudence that would unnecessarily cause international turmoil. The just war tradition also granted kingdoms legitimacy, as kings and rulers were put in a legitimate position to exercise authority, and private actors were not authorised to wage war. During the 2oth century norms of warfare rooted in the just war tradition were meant to be applied by modern states. Authors in the just war tradition expressed their preference for a stable international order, the legitimacy of which relied on shared norms of restraint and a system of reciprocity among peers. Moreover, just war tradition thinking was also a response to prevailing views about what the use of force should be in the conduct of Realpolitik or according to the realist explanatory model

4 Gentili, De Jure Belli Libri Tres, (1933). See Book II, Chapter 6 'On Poison'.

5 See Price, The Chemical Weapons Taboo, (1997). 
of international politics (i.e. the sheer pursuit of interest). ${ }^{6}$ Walzer's seminal work, Just and Unjust Wars, was originally published in 1977 in the aftermath of Vietnam, and it advocated some of the fundamental rules that Grotius and other thinkers had set out in the just war tradition. Those rules are meant to create stability and to minimise harm.

In the 1990s, as Realism was weakened by the end of the Cold War, constructivism emerged as a serious challenger to its approach in the field of IR. Constructivism's focus on norms meant a move from the study of the more substantive norms in the just war tradition to the analysis of constitutive norms in sociological terms. Contructivists analysed why the move toward the refusal of undue suffering and the protection of civilians was made possible. ${ }^{7}$ They highlighted the role of 'moral entrepreneurs' and pointed to social change within Western societies, members of which were increasingly more informed about human suffering and injustice and less indifferent to them than they had been in the past. ${ }^{8}$ Constructivists have also analysed the impact of human rights (HR) in international politics, while echoing an increasing consciousness about their role in international politics. ${ }^{9}$ This is important for the ethics of war as human rights have had a strong impact on the debates on humanitarian interventions and, more recently, around $\mathrm{R}_{2} \mathrm{P}$.

The early 2ooos marked a new shift and, this time, a radical move from the constitutive to the substantive. Analytical philosophers emerged as a new force in the field of the ethics of war. They argued in favor of 'pure morality' and formulated a response both to the just war tradition and to constructivism. Compared with the just war tradition, ethics of war theory is constructed as a fact-independent theory of ethics. ${ }^{10}$ It also stands in contrast to constructivism. Ethical norms are not socially contingent: they are the product of the moral rationality of individuals. Dissimilar to the substantive approach of the just war tradition and to the constitutive analysis of constructivism, the ethics of war theory presents an individualistic approach to the laws of warfare. The

$6 \quad$ Walzer, Just and Unjust Wars (1977). See Chapter 1 'Against Realism. Realists often praise themselves for being amoral'. However, Realism is also normative: see Beitz, Political Theory, (1999) and Lang, Political Theory, (2004).

7 On aerial bombings and precision in warfare: Thomas, The Ethics of Destruction (2001).

8 On non-state actors as moral entrepreneurs - a concept imported from sociology and the work of Howard Becker — see: Nadelmann, 'Global Prohibition Regimes', (1990). On HR groups as norms entrepreneurs, see: Finnemore and Sikkink, 'International Norms Dynamic', (1998).

9 During the 8os, authors such as Hedley Bull and R.B.J. Vincent, from the rationalist English school of IR have contributed to that consciousness. Bull, The Anarchical Society, (1977). Vincent, Human Rights, (1986).

10 See, most particularly, McMahan, 'The Ethics of Killing in War', (2004. 
theory focuses mostly on individual dilemmas that soldiers have to face when they use force in targeted killings operations (such as in the context of the aftermath of 9/11). The individualistic approach to the ethics of war also emerged in a context where the traditional distinction between international humanitarian law (i.e. the laws of war rooted in jus in bello) and human rights law was questioned. When it fights Al-Qaïda or ISIs, for example, the US considers members of organisations such as Al-Qaïda or Isis 'unlawful combatants' and therefore it does not grant them those rights that protect normal combatants in warfare according to IHL. Hence, human rights law should apply to them, although one could argue that both the US and Al-Qaïda or IsIS are engaged in an international conflict. In many other instances uncertainty prevailed and continues to prevail over which regime of norms should apply. ${ }^{11}$ In the context of such uncertainty the ethics of war has moved away from the distinction between IHL and HR laws and has reframed the debate about the use of force from an ethical individualistic standpoint, which has proved to be appealing.

In one of the most recent moves towards a constitutive approach to norms, and as a reaction itself to the abstract, individualistic approach to the ethics of war, social scientists have stressed the importance of the strategic uses of norms. Critical theorists have criticised the uses and abuses of anti-terrorist legal norms. ${ }^{12}$ Lawyers have also initiated an important debate on 'lawfare', i.e. the pursuit of power struggles on the legal terrain. ${ }^{13}$ Although this Special Issue argues in favor of a critical approach, its authors do not subscribe to the traditional critical theory approach, mostly grounded on a (debatable) interpretation of Foucauldian social theory according to which norms are fully determined by power. ${ }^{14}$ The contributions are more in alliance with those analyses that point to the strategic analysis of norms while also making explicit normative claims and considering that norms are not fully determined by power. ${ }^{15}$

We argue that the moment is ripe for a new approach in the study of norms of warfare that would reduce the gap between the normative and the empirical and combine the substantive and the constitutive. Contributions to this Special Issue argue accordingly for a conjunctive approach.

11 On the discussion of the difference between HR and IHL approaches in the context of the Palestinian-Israeli conflict, see Kretzmer, “Targeted Killing”, (2005).

12 Among others, Reed, The Biopolitics, (2006). This approach has been met with some criticism: see Chandler, 'Critiquing Liberal Cosmopolitanism', (2009), pp. 53-70.

13 Dunlap, 'Law and Military Interventions', (2001).

14 Foucault's relativism is also questionable. For an anti-relativist interpretation of the genealogical model, see: Taylor, 'Foucault on Freedom and Truth', (1984). 
There are both epistemic and political reasons why this change of approach is required. Epistemically, analytical philosophers face growing criticism both from just war tradition authors and political scientists, and these critiques are well taken. ${ }^{16}$ Nor are just war tradition approaches immune from criticism either. Ethics of war theorists have critiqued just war tradition thinking since it has not provided clear answers to ethical dilemmas in warfare. Moreover, although just war tradition thinkers discuss historical examples and comment on contemporary states of affairs, they very seldom explain these cases. They do not use sufficiently the social sciences and its explanatory/interpretive tools to make normative arguments. The explanation of social facts is important when addressing issues such as just cause or proportionality, as social science informs us about decision-making and the measurement of force. The explanation of facts is also extremely relevant in the critique of power when attempting to make states accountable.

There are political and structural reasons why a new theoretical outlook on international norms is required. Since the early zooos the divide between the international and the domestic has become more and more blurred, and issues about the use of force have strong implications at the domestic level (for example, measures taken to fight terrorism). Due to the nexus between the international and the domestic this Special Issue considers that a normative discussion on the norms of warfare should include a social analysis of what are socially acceptable norms that are meaningful to individuals in the context of their own domestic politics.

\section{The methodological case for entanglement}

Although there are overlaps between these three different realms of study, the study of ethics is primarily divided into three branches in the contemporary literature on ethics: applied ethics, normative ethics, meta-ethics. ${ }^{17}$ While showing the entanglement between the normative and the empirical, authors in this Special Issue address questions that are related to each of these different domains. Some papers pertain, in essence, to one single domain; in other papers there is an overlap among applied ethics, normative ethics and meta-ethics.

16 From the perspective of the just war tradition, among others, see O'Discoll, Victory, (2019). Walzer himself expressed his reservations vis-à-vis the ethics of war theory. For a critique of the individualistic approach to ethics of war, see Zohar, 'War Individualist Ethics', (1993), and Crawford, 'Individual and Collective', (2007). 
Applied ethics is an important sub-field in the study of the ethics of war and is mostly a context-based analysis of moral behavior in warfare. Several authors in this special issue explore specific contemporary wars and conflicts and adopt an applied ethics approach while providing solutions to the difficult challenges that are confronted by those who fight or argue about justice in warfare. Both Chris Brown and Pablo Kalmanovitz address in their papers the issue of reciprocity, one of the main pillars of the modern and contemporary laws of war. They examine the pertinence of the contemporary laws of war in a world where that reciprocity is lacking, as in the case of asymmetric warfare (Brown) or in the context of Non-International Armed Conflicts (Kalmanovitz). According to Brown this is a real challenge for applied ethics, forcing us to elaborate new norms of warfare. According to the author, 'virtue ethics' could provide the practical solution to this challenge. In the context of the absence of reciprocity, Kalmanovitz discusses the interaction between the normative logic of the laws of war and the logic of criminal law that has come to be applied to military operations. He argues in favor of a new balance between criminal courts and the state's judicial and military institutions. Matthew Evangelista also discusses practical issues in warfare and analyses the legal implications of the Chechen wars. Evangelista points to some of the negative consequences of human rights based accusations against Russia and calls for the examination of the conditions under which legal efforts at expanding human rights during armed conflict can succeed without provoking a damaging backlash.

Several authors in this Special Issue adopt a normative approach to the study of plausible norms in warfare, i.e. appropriate norms that 'make sense' to those who should abide by them and that are both socially and morally meaningful. These authors explain the conditions upon which plausible norms could emerge and discriminate between norms of warfare that might be prima facie appropriate and desirable but are not satisfying and those that would be more appropriate. Both Renaud-Philippe Garner and Richard Price explore this question from a psychological perspective. Garner uses insights from social psychology to critique the current cosmopolitan and individualistic approach to the ethics of war. He also shows that the claim for plausible norms of warfare should include explanation of human affects and their political implications. Price opens the door to a discussion that brings together the neuro-sciences/psychology and the ethics of war while focusing on a possibilistic analysis of the norm of non-combatant immunity. He calls for emotional regulation in global affairs based on the findings of research in the neuro-sciences. The article by Thierry Balzacq and Elise Rousseau also relates to psychology and analyses the logic of blame in international 
politics. According to Balzacq and Rousseau, blame constitutes a mechanism of defence used by states when witnessing wrongdoings in order to make non-intervention morally acceptable. They argue, however, that from a normative perspective the very act of blaming should trigger responsibility. The authors argue, accordingly, that states actually become complicit in the wrongdoing of other actors, states or non-states, whenever they violate the moral obligations that blaming connotes.

Arguing in favour of reducing the gap between the normative and the empirical has deep meta-ethical implications. These implications appear in papers by Brown, Garner and Price, and they are at the centre of two other articles in this special issue. Ariel Colonomos argues that ethical arguments in warfare are fact-dependent and that, therefore, they require the social sciences since disciplines such as sociology, political science and International Relations deal with the interpretation/explanation of facts. Colonomos shows that the unidimensionality of both the just war tradition and the ethics of war is problematic and, based on a multi-level analysis grounded in the social sciences, he discusses normatively the problems posed by hostage-taking crises and proportionality assessment. Whereas for Colonomos, the ethics of war should include the social sciences, based on practice theory, Mervyn Frost argues in his paper the converse, that the description of facts is embedded within normative theory. Frost's paper then deploys a radical interpretivist approach to understanding what has come to be known as asymmetrical war.

\section{Plausible and morally truthful norms in liberal democracies}

Most papers in this special issue focus on emergent norms of warfare while their authors ask themselves if these are plausible norms. Emerging norms become plausible norms, and therefore universal substantial norms, when they are compatible with the capacity, the emotions and the cognitive resources of those who fight and those who are in the position to authorise or limit the use of force. Plausible norms often rely, moreover, on core norms - such as self-defence or the minimising of undue harm - norms which endure through time and are subject to reinterpretation in new historical contexts. ${ }^{18}$

18 On the distinction, for example, between 'thick' and 'thin' norms (i.e. a maximalist and a minimalist approach to ethics) see Walzer, Thick and Thin, (1996). On temporal relativism, see Bernard Williams' classic Ethics and the Limits of Philosophy (1985). 
Authors in this special issue limit their enquiry to liberal democracies, in circumstances when these states use force or when they witness wrongdoings and abuses outside their borders. Plausible norms are ideas that lie at the center of a democratic 'marketplace of ideas' where moral entrepreneurs place them under scrutiny. Plausible norms must resist the test of public and democratic debate.

This Special Issue does not argue in favor of an ideal normative theory: plausible norms are non-ideal rules of regulation and behavior. Its authors do not argue, either, in favour of moral truth: plausible norms are norms that are morally truthful. ${ }^{19}$ Truthfulness in turn is a search for moral truth, one based on the capacity to search for ethical standards of behavior according to whom we are and to where we stand.

The goal of this Special Issue is to develop a critical normative approach to the ethics of war that challenges, at one and the same time the lack of contextualisation of norms, on the one hand, and the non-normative stance of social scientists, on the other. This normative approach is critical both in the sense that it aims to realign orientation in the ethics of war and in the sense that this realignment has practical as well as theoretical implications.

\section{Bibliography}

Beitz, Charles, Political Theory and International Relations, (Princeton, Princeton University Press, 1999).

Bull, Hedley, The Anarchical Society, (New York, Columbia University Press, 1977).

Chandler, David, 'Critiquing Liberal Cosmopolitanism? The Limits of the Biopolitical Approach', International Political Sociology, n. 3 (2009), pp. 53-70.

Copp, David, 'Introduction: Metaethics and Normative Ethics', in Oxford Handbook of Ethical Theory, (Oxford, Oxford University Press, 2007), pp. 3-35.

Crawford, Neta, 'Individual and Collective Moral Responsibility for Systematic Military Atrocity', Journal of Political Philosophy, Vol. 15, n. 2 (2007), pp. 187-212.

Dunlap, Charles, 'Law and Military Interventions: Preserving Humanitarian Values in 21st Century Conflicts', Working Paper, (Harvard University, Kenney John F. School of Government, 2001).

Fazal, Tanisha, Wars of Law: Unintended Consequences in the Regulation of Armed Conflict, (Ithaca, Cornell University Press, 2018).

19 On the distinction between truth and truthfulness, see also Williams, Truth and Truthfulness (2005). 
Finnemore, Martha, and Sikkink, Kathryn 'International Norms Dynamic and Political Change', International Organization, Vol. 52, N. 4 (1998), pp. 887-917.

Gentili, Alberico, De Jure Belli Libri Tres, (Oxford, Clarendon Press, 1933).

Gross Michael, The Ethics of Insurgency - A Critical Guide to Just Guerilla Warfare, (Cambridge, Cambridge University Press, 2014).

Johnson, James Turner, 'Thinking comparatively about Religion and War', Journal of Religious Ethics, Vol. 36, No. 1 (March, 2008), pp. 157-79.

Kretzmer, David, "Targeted Killing of Suspected Terrorists: Extra-Judicial Executions or Legitimate Means of Defence?" European Journal of International Law 16, no. 2 (2005), pp. 171-212.

Kuhn, Thomas, The Structure of Social Revolutions, (Chicago, Chicago University Press, 1962).

Lang, Anthony, Political Theory and International Affairs: Hans J. Morgenthau on Aristotle's the Politics, (Westport CT, Greenwood Press, 2004).

McMahan, Jeff 'The Ethics of Killing in War', Ethics, Vol. 114, July (2004), pp. 693-733.

Nadelmann, Ethan, 'Global Prohibition Regimes: The Evolution of Norms in International Society', International Organization, Vol. 44, N. 4 (1990), pp. 479-526.

O'Discoll, Cian, Victory: The Triumph and Tragedy of Just War, (Oxford, Oxford University Press, 2019).

Price, Richard, The Chemical Weapons Taboo, (Ithaca, Cornell University Press, 1997).

Reed, Julian, The Biopolitics of the War on Terror: Life Struggles, Liberal Community and the Defense of Logistical Societies, (Manchester, Manchester University Press, 2006).

Taylor, Charles, 'Foucault on Freedom and Truth', Political Theory, Vol. 12, N. 2 (1984), pp. $15^{2-183}$.

Thomas, Ward, The Ethics of Destruction, (Ithaca Cornell University Press, 2001).

Vincent, Raymond. J. Human Rights in International Relations, (Cambridge, Cambridge University Press, 1986).

Walzer, Michael, Just and Unjust Wars, (New York, Basic Books, 1977).

Walzer, Michael, Thick and Thin: Moral Argument at Home and Abroad, (University Notre Dame University Press, 1996).

Williams, Bernard, Ethics and the Limits of Philosophy, (William Collins \& Sons, 1985). Williams, Bernard, Truth and Truthfulness, (Princeton, Princeton University Press, 2005).

Zohar, Noam, "War Individualist Ethics: Against the Conscription of 'Self-Defense", Political Theory, Vol. 21, n. 4 (1993), pp. 6o6-622. 